\title{
Can otolith chemistry detect the population structure of the shad hilsa Tenualosa ilisha? Comparison with the results of genetic and morphological studies
}

\author{
David A. Milton ${ }^{1, *}$, Simon R. Chenery ${ }^{2}$ \\ ${ }^{1}$ CSIRO Division of Marine Research, PO Box 120, Cleveland, Queensland 4163, Australia \\ ${ }^{2}$ Analytical Geochemistry Group, British Geological Survey, Keyworth, Nottingham NG12 5GG, United Kingdom
}

\begin{abstract}
The stock structure of the valuable tropical shad Tenualosa ilisha ('hilsa') has been studied in Bangladesh and India by analysing morphometric and genetic data. However, these studies had a narrow geographic scope and their results conflict. We made a comprehensive study of the stock structure of hilsa with otolith microchemistry in conjunction with complementary genetic and morphometric studies of the same fish. We examined the trace-element composition of the otolith cores of hilsa with laser-ablation inductively coupled plasma mass spectrometry. The otoliths of fish from 19 collections at 13 sites in Bangladesh and 6 collections at 4 sites from elsewhere within the species' range (Kuwait, SE India, Myanmar and Sumatra) were analysed for 8 trace elements. Samples were collected from Bangladesh mainly during 2 comprehensive surveys (1996 and 1997). When these data were analysed separately, there were significant differences in otolith composition among sites. However, when both years' data were analysed together, there were few significant differences among sites, and some sites separated by hundreds of kilometres that were sampled in different seasons and years had very similar compositions. This was in spite of both large seasonal intra-site and between-site differences in water chemistry. Repeat samples from 5 sites (4 in Bangladesh) showed that differences in otolith composition at a single site were significant and of similar magnitude to that found among sites. Our results support the conclusion from allozyme studies that there is extensive movement and mixing of hilsa throughout Bangladesh, and therefore the population should be managed as a single stock. Genetic and otolith data both showed that hilsa from SE India and Myanmar were not significantly different from fish collected in coastal areas of Bangladesh, and suggest that hilsa in the Bay of Bengal were a single stock. Both methods also separated fish from Sumatra and Kuwait from other sites, providing strong evidence of separate stocks in those regions. In contrast, morphometric studies separate fish from several nearby sites in Bangladesh, but these differences are likely to be largely due to phenotypic variability and are unlikely to be geneticallybased. Our results suggest that otolith microchemistry may be a good proxy for genetic structure at large scales where differences in water chemistry are highly likely. However, for sedentary species and those without distinct spawning and non-breeding areas, it requires both comprehensive and repeated sampling at finer scales before any confidence should be placed in the results.
\end{abstract}

KEY WORDS: Shad · Tenualosa $\cdot$ Otolith microchemistry $\cdot$ Stock structure $\cdot$ Bay of Bengal Resale or republication not permitted without written consent of the publisher

\section{INTRODUCTION}

Both the concept and definition of stock structure of a species have long been relevant to open-water fish-

*E-mail: david.milton@marine.csiro.au eries management because the identification of discrete populations within stocks is critical to rational resource exploitation (Smith et al. 1990). The numerous definitions of stocks as they apply to fisheries mostly involve defining population(s) of fish that maintain their genetic integrity over time (e.g. Cushing 1968, Booke 1981). In practice, to be useful for fisheries 
resource management, stocks need to be easily and accurately defined (Kutkuhn 1981), which is currently done with genotypic or phenotypic markers that are stable and repeatable (Booke 1999).

For most marine and estuarine species, stock structure is difficult or impossible to measure directly, as methods to measure the extent of larval homing have not been developed (Thresher 1999). Stocks have thus usually been delineated by indirect methods, such as studies of larval advection, parasite loads, morphometric and genetic variation or locating and mapping discrete spawning areas. As all these methods have limitations in the scope and strength of inferences that can be derived, alternative approaches continue to be evaluated.

One alternative approach is to analyse the chemical composition of calcified structures such as fish otoliths. Thresher's (1999) review of the potential of this approach identified several issues that cast doubt on its value for delineating stock structure. Nonetheless, he thought its potential should be further explored by research that (1) compared the stock structures obtained from otolith microchemistry with those obtained from other sources such as tagging and genetic studies, and (2) assessed the stability and repeatability of delineating the structure of a stock from the otolith microchemistry (Thresher 1999).

The anadromous shad Tenualosa ilisha ('hilsa') is one of the most important species of coastal and estuarine fish to the peoples of southern Asia (Blaber 1997); the annual commercial catch exceeds $300000 \mathrm{t}$ (FAO 1995). In Bangladesh, the annual catch of over $200000 \mathrm{t}$ accounts for $20 \%$ of national fisheries production (FAO 1995). Hilsa is caught in coastal and marine waters from Kuwait in the west, to the Bay of Bengal as far east as Myanmar (Whitehead 1985), and there is an isolated population in northern Sumatra (Fig. 1). This fish is also found in all the large rivers, and spawning fish have been caught as far as $1200 \mathrm{~km}$ upstream. Most, however, live within $100 \mathrm{~km}$ of the coast (Whitehead 1985).

Previous hilsa stock structure studies have mainly examined changes in a similar range of morphological traits. These morphometric studies examined different characters and have varied greatly in the stock structures they suggest: from no variation among several rivers (Pillay 1957) to as many as 4 partly overlapping stocks in the lower Meghna River in Bangladesh (Rahman \& Moula 1992, Rahman et al. 1997). These apparently conflicting results may be expected given that phenotypic variation in morphological characters has

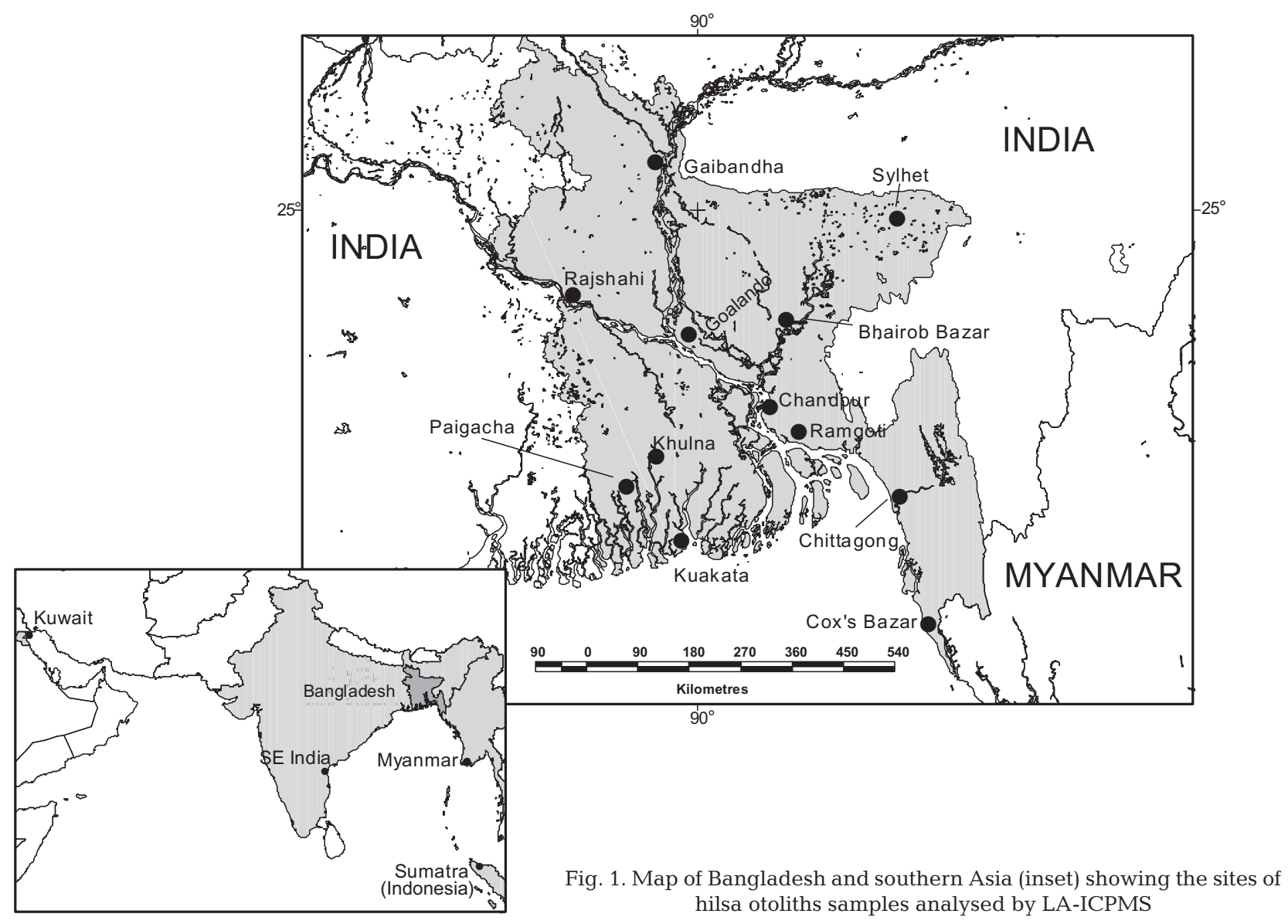


both environmental and genetic components (Swain \& Foote 1999).

Genetic studies should be more powerful for identifying stocks. The genetic studies of hilsa have focussed mainly on fish in Bangladeshi waters. They have identified between 1 and 3 stocks. Dahle et al. (1997) sampled at 3 sites about $150 \mathrm{~km}$ apart (riverine, coastal and marine) and used RADP fingerprinting to genetically separate fish from each site. Rahman et al. (1997) sampled at 2 sites (riverine and coastal) using starch gel electrophoresis, and found that they were also genetically distinct. Hussain et al. (1998) and subsequently Salini et al. (unpubl. data) made a more comprehensive electrophoretic and morphometric study, sampling 9 riverine, coastal and marine sites throughout Bangladesh and other sites in adjacent Myanmar and southeastern India (Fig. 1). They found no evidence of genetic separation between the samples. However, they found that fish from elsewhere in the species' range (Kuwait and Sumatra) were genetically distinct.

Given the wide variation in the results of the morphometric and genetic studies, an alternative independent method is needed to clarify the stock structure of hilsa. The aims of this study were to (1) examine the spatial variation in hilsa otolith chemistry, focussing on Bangladesh, (2) assess the reproducibility of patterns by examining multiple samples of fish from the same sites and (3) compare the results with those from complementary genetic and morphometric studies of the same fish (Hussain et al. 1998, Salini et al. unpubl data) and morphometric studies of fish from the same region (Rahman \& Moula 1992, Rahman et al. 1997), thereby assessing the congruence of the otolith microchemistry results and those from other methods for identifying hilsa stock structure.

\section{MATERIALS AND METHODS}

Sampling and sample preparation. Hilsa were collected by either experimental gillnetting, or buying them from commercial fishers or fresh from local markets at 12 sites and 18 collections throughout Bangladesh and 4 sites elsewhere within the species' range (Fig. 1). To minimise the effects of differences among sample collections of handling artefacts on measurements of trace metal concentrations, both saggittae were taken as soon as possible after collection (Proctor \& Thresher 1998, Milton \& Chenery 1998). Fish were kept on ice when it was impractical to remove otoliths immediately after capture. As hilsa fishing is a daytime activity, most otoliths were removed within $10 \mathrm{~h}$ of the death of the fish. Successive collections were made at 5 sites (4 in Bangladesh) to assess similarity in results over 2 yr (1996-97).
On each sampling occasion in Bangladesh when otoliths were collected for elemental analysis, duplicate water samples were collected. All samples were taken from mid-water, at least $10 \mathrm{~m}$ from the riverbank at the site where the fish were caught, or $100 \mathrm{~m}$ offshore for the coastal samples. Water temperature and salinity were recorded at the same time with a TPS multimeter probe. Water samples were fixed to $1 \%$ nitric acid and stored in the refrigerator until analysed. Prior to analysis, samples were filtered through a $0.45 \mu \mathrm{m}$ paper and analysed with a Fisons/ARL 3580 Quantovac ICP-AES. During analysis, they were handled using the protocols of the ongoing, long-term multi-element Geochemical Baseline Survey of the Environment $\left(\mathrm{G}-\mathrm{BASE}^{\circledR}\right.$ ) being undertaken by the British Geological Survey (BGS).

In the laboratory, fish were measured (standard length, SL, in $\mathrm{mm}$ ), weighed ( $\mathrm{g}$ ) and measured for the same suite of 9 morphometric measurements and meristic counts of Quddus et al. (1984a) and Rahman et al. (1997). Fish were dissected, sexed and a sample of liver and muscle frozen for genetic analysis (Hussain et al. 1998, Salini et al. unpubl. data). The otoliths were then removed and cleaned of adhering tissue with thin glass rods, dried with tissue paper and stored in clean, labelled plastic bags. Each otolith was weighed ( $\pm 0.1 \mathrm{mg})$, and where possible, the left otolith of fish aged as 1+yr old from counts of daily increments (15 to $25 \mathrm{~cm}$ ) (Blaber et al. 1998) in each sample were chosen for analysis. In some cases, such as in Myanmar, fish of this size were not available and older fish $(2+\mathrm{yr}$ old $)$ had to be analysed.

The otoliths were mounted in thermoplastic cement on a labelled microscope slide and ground along the transverse axis with heavy-duty silicon carbide paper until the core region of the otolith was exposed. The otolith was then polished to the core with 1200 grade wet and dry sandpaper moistened with doubledistilled water. Water use was kept to a minimum during otolith preparation to minimise and standardise any preparation bias (Proctor \& Thresher 1998). To remove any contamination, the surface was wiped vigorously after polishing with a piece of tissue paper moistened with $0.5 \mathrm{M}$ aristar nitric acid. The slides were then placed in plastic bags until analysed by laser-ablation inductively coupled plasma mass spectrometry (LA-ICPMS).

Laser ablation. For LA-ICPMS, the otolith being investigated was placed in a perspex ablation cell under a microscope objective and illuminated in transmitted light to identify the growth zones of the otoliths. After the core (region of the otolith just outside the hatch check) was placed under the crosswire, the laser was focussed on the sample surface in reflected light and fired through the microscope objective lens. The 
ablated material was transported from the ablation cell to the ICPMS instrument in inert argon gas flow. The laser (pulsed Nd: YAG) was run in Q-switched mode at $266 \mathrm{~nm}$. Three ablations were made at the core and rim of all otoliths analysed. The core samples were made in the growth zone immediately outside the hatch check that corresponded to the first week of larval growth. The results of the rim analysis will be reported elsewhere.

The isotopes in highest concentration in the otoliths were determined from solution ICPMS of an initial sample of 6 otoliths. These results were used to identify the best isotopes for analysis. For the main part of the study, the ICPMS was then operated by peak jumping mode rather than scanning mode to maximise the signal from the isotopes of interest.

Calcium was used as an internal standard to compensate for the poor precision in the analytical signal, which is caused by variations in the mass of the material ablated (Campana et al. 1994). Calcium concentration was assumed from the stoichiometry of calcium carbonate to be $400000 \mu \mathrm{g} \mathrm{g}^{-1}$ and the concentrations of other elements were estimated against the Ca concentration. This enabled the ICPMS to be calibrated with aqueous solutions containing all isotopes of interest (Thompson et al. 1989, Chenery \& Cook 1993). The accuracy of this method of calibration is close to that of solution ICPMS calibrations (Querol \& Chenery 1995). Detection limits depend on the amount of material ablated. For an ablated mass equivalent to a crater $20 \mu \mathrm{m}$ in diameter and $15 \mu \mathrm{m}$ deep, the following list gives the theoretical detection limits (in $\mu \mathrm{g} \mathrm{g}^{-1}$ ) during our analysis for the list of elements examined: ${ }^{7} \mathrm{Li}: 0.2-1.7,{ }^{23} \mathrm{Na} 7-22,{ }^{24} \mathrm{Mg}: 0.3-5.4,{ }^{27} \mathrm{Al}: 0.9-4.8$, ${ }^{55} \mathrm{Mn}: 0.3-1.2,{ }^{66} \mathrm{Zn}: 0.8-2.6,{ }^{88} \mathrm{Sr}: 0.1-0.6,{ }^{138} \mathrm{Ba}: 0.1-0.4$. These were taken as 3 standard deviations above the mean blank (background) count of each isotope for that day.

ICPMS operating conditions and protocols used during otolith ablations are described elsewhere (Milton et al. 1997, Milton \& Chenery 1998). Before each group of ablations of an otolith, a blank was determined for subtraction from that group of ablations. These blanks are used to calculate the detection limit for each isotope during that analytical session. At the beginning and end of every day a NIST glass reference material was analysed to check the calibration and identify any inconsistencies. In this way we minimised the possibility of systematic within-day and betweenday differences in instrument operation.

All samples were randomly assigned a sequential coded label in the laboratory before they were analysed by LA-ICPMS, and the history of each otolith was unknown before analysis. Before laser ablation the order of samples was further randomised to remove any possibility of operator bias. As a result, betweenday effects should be noise rather than systematic errors.

Data analysis. The mean [metal:Ca] ratios of the 8 elements at the core of each otolith was calculated from the 3 replicate ablations. The ratios of most elements were not normally distributed. All data were natural logarithm transformed prior to analysis. Ratios were compared among replicate otolith collections (sites and dates) (Table 1, Fig. 1) by MANCOVA with otolith weight as a covariate and canonical discriminant analysis. As the sample sizes in many samples were small, a common covariance matrices was assumed. However, the covariance matrix of several larger samples $(n>20)$ were examined and found to be similar ( $p>0.1$, Bartlett's test, Morrison 1976). The data from Bangladesh were separated by year of collection and the 1996 and 1997 samples analysed separately. The canonical variate values of each sample were compared by MANCOVA with samples blocked for sex and otolith weight as the covariate. Samples that had similar means were grouped. This enabled the 19 otolith collections from Bangladesh to be reduced to 10 sample groups (1996 and 1997 samples) or were collected in 1998 or 1999. These sample groups were compared to the samples from other countries in a similar way.

To get a feel for the relative similarity of samples from different regions and to examine how this relatedness compares with the degree of genetic similarity among samples from the same geographic area (Hussain et al. 1998, Salini et al. unpubl data), we undertook discriminant function analysis of the otolith trace element composition. We used the cross-validation algorithm DISCRIM (SAS 1989) to determine the classification accuracy (Wells et al. 2000).

\section{RESULTS}

In all, the cores of 338 hilsa otoliths from 18 collections in Bangladesh and 6 from other parts of the range were examined by LA-ICPMS (Table 1). Sampling spanned 3 yr. Five sites were sampled more than once: 4 in Bangladesh and 1 from northeastern Sumatra, Indonesia. The mean length and the sex ratio varied between collections, as larger fish were female. Eight elements were routinely detected by LA-ICPMS in concentrations above their detection limits in the majority of fish in all samples ( $\mathrm{Li}, \mathrm{Na}, \mathrm{Mg}, \mathrm{Al}, \mathrm{Mn}, \mathrm{Zn}$, $\mathrm{Sr}$, and $\mathrm{Ba}$ ). One element, $\mathrm{Li}$, was found in concentrations that were often within its overall range of detection limits. However, as over $97 \%$ of all measurements were above the detection limit on the day that they were measured, Li was retained in the analysis. 
Table 1. Mean length, weight and otolith weight of the sample collections of hilsa Tenualosa ilisha otoliths that were examined by LA-ICPMS (SL = standard length) and water temperature and salinity at the time of collection. See Fig. 1 for the location of sampling sites. Collection sites in bold are from sites outside Bangladesh and all sites are ordered from west to east

\begin{tabular}{|c|c|c|c|c|c|c|c|c|}
\hline Site & $\mathrm{n}$ & Date & $\begin{array}{c}\text { Water } \\
\text { temperature }\left({ }^{\circ} \mathrm{C}\right)\end{array}$ & $\begin{array}{l}\text { Salinity } \\
(\%)\end{array}$ & $\begin{array}{l}\mathrm{SL} \pm \mathrm{SE} \\
(\mathrm{mm})\end{array}$ & $\begin{array}{c}\text { Weight } \pm \text { SE } \\
(\mathrm{g})\end{array}$ & $\begin{array}{l}\text { Sex ratio } \\
(\mathrm{M}: \mathrm{F})\end{array}$ & $\begin{array}{l}\text { Otolith weight } \\
\quad(\mathrm{mg}) \pm \mathrm{SE}\end{array}$ \\
\hline Kuwait & 16 & Jun 96 & 27 & - & $303 \pm 9$ & $569 \pm 58$ & $1: 15$ & $9.3 \pm 0.5$ \\
\hline SE India & 26 & Aug 98 & 26 & - & $330 \pm 5$ & $871 \pm 47$ & $4: 22$ & $12.4 \pm 0.5$ \\
\hline Paigacha & 19 & Aug 97 & 22 & 2 & $330 \pm 8$ & $931 \pm 61$ & $11: 8$ & $11.4 \pm 0.3$ \\
\hline \multirow[t]{2}{*}{ Khulna } & 7 & Jul 96 & 23 & 10 & $258 \pm 34$ & $496 \pm 192$ & $4: 3$ & $8.5 \pm 1.6$ \\
\hline & 14 & May 97 & 23 & 12 & $300 \pm 5$ & $498 \pm 34$ & $12: 2$ & $10.0 \pm 0.4$ \\
\hline Kuakata & 9 & Jul 96 & 24 & 14 & $321 \pm 15$ & $799 \pm 130$ & $6: 3$ & $11.1 \pm 1.2$ \\
\hline Rajshahi & 19 & Aug 97 & 22 & 0 & $299 \pm 18$ & $667 \pm 135$ & $14: 5$ & $10.4 \pm 1.1$ \\
\hline Gaibandha & 20 & Aug 97 & 22 & 0 & $222 \pm 11$ & $262 \pm 42$ & $18: 2$ & $6.1 \pm 0.7$ \\
\hline \multirow[t]{3}{*}{ Goalando } & 9 & Jul 96 & 23 & 0 & $362 \pm 14$ & $1050 \pm 97$ & $3: 6$ & $14.5 \pm 0.7$ \\
\hline & 9 & Oct 96 & 25 & 0 & $263 \pm 23$ & $517 \pm 130$ & $5: 4$ & $8.7 \pm 1.1$ \\
\hline & 10 & May 97 & 23 & 0 & $270 \pm 10$ & $442 \pm 55$ & 10:0 & $7.8 \pm 0.6$ \\
\hline Bhairob Bazar & 20 & Aug 97 & 22 & 0 & $211 \pm 6$ & $197 \pm 14$ & $15: 5$ & $5.8 \pm 0.4$ \\
\hline Sylhet & 17 & May 99 & 21 & 0 & $170 \pm 9$ & $124 \pm 33$ & $13: 4$ & $4.7 \pm 0.4$ \\
\hline \multirow[t]{3}{*}{ Chandpur } & 10 & Jul 96 & 23 & 0 & $371 \pm 21$ & $954 \pm 136$ & $2: 8$ & $13.6 \pm 1.1$ \\
\hline & 9 & Oct 96 & 25 & 0 & $302 \pm 12$ & $674 \pm 101$ & $4: 5$ & $10.0 \pm 0.7$ \\
\hline & 9 & May 97 & 23 & 0 & $318 \pm 14$ & $660 \pm 85$ & $4: 5$ & $10.5 \pm 0.7$ \\
\hline \multirow[t]{2}{*}{ Ramgoti } & 7 & Jul 96 & 23 & 4 & $377 \pm 11$ & $1029 \pm 95$ & $0: 7$ & $13.5 \pm 1.0$ \\
\hline & 12 & Feb 99 & 26 & 2 & $322 \pm 7$ & $795 \pm 47$ & $1: 11$ & $11.7 \pm 0.5$ \\
\hline Chittagong & 14 & May 97 & 24 & 14 & $259 \pm 4$ & $289 \pm 13$ & $11: 3$ & $8.2 \pm 0.3$ \\
\hline Cox's Bazar & 12 & July 96 & 22 & 17 & $258 \pm 10$ & $413 \pm 59$ & $7: 5$ & $8.4 \pm 0.5$ \\
\hline Myanmar & 28 & Aug 98 & 26 & - & $414 \pm 4$ & $1812 \pm 50$ & $0: 28$ & $17.8 \pm 0.4$ \\
\hline \multirow[t]{3}{*}{ Sumatra } & 8 & Nov 96 & 28 & - & $263 \pm 6$ & $385 \pm 21$ & $5: 3$ & $7.6 \pm 0.3$ \\
\hline & 20 & Apr 97 & 26 & - & $313 \pm 6$ & $748 \pm 57$ & 9:11 & $10.0 \pm 0.5$ \\
\hline & 8 & Nov 97 & 28 & - & $283 \pm 8$ & $604 \pm 60$ & $0: 8$ & $8.6 \pm 0.5$ \\
\hline Total & 333 & & & & $296 \pm 4$ & $685 \pm 27$ & $162: 176$ & $10.1 \pm 0.2$ \\
\hline
\end{tabular}

Table 2. Mean water (metal:Ca) ratios of the 8 trace metals (in mol) in duplicate samples taken at the sites in Bangladesh where hilsa were collected. Concentrations of Li below the detection limit of the ICP-AES are shown in italics

\begin{tabular}{|c|c|c|c|c|c|c|c|c|c|c|}
\hline Site & Date & $\begin{array}{c}\mathrm{Li} \\
\left(\mathrm{mmol} \mathrm{mol}^{-1}\right)\end{array}$ & $\begin{array}{c}\mathrm{Na} \\
\left(\mathrm{mol} \mathrm{mol}^{-1}\right)\end{array}$ & $\underset{\left(\mathrm{mol} \mathrm{mol}^{-1}\right)}{\mathrm{Mg}}$ & $\underset{(\mathrm{mmol} \mathrm{mol}}{\mathrm{Al}})$ & $\begin{array}{c}\mathrm{Ca} \\
\left(\mu \mathrm{g} \mathrm{g}^{-1}\right)\end{array}$ & $\begin{array}{c}\mathrm{Mn} \\
\left(\mathrm{mmol} \mathrm{mol}^{-1}\right)\end{array}$ & $\begin{array}{c}\mathrm{Zn} \\
\left(\mathrm{mmol} \mathrm{mol}^{-1}\right)\end{array}$ & $\begin{array}{c}\mathrm{Sr} \\
\left(\mathrm{mmol} \mathrm{mol}^{-1}\right)\end{array}$ & $\begin{array}{c}\mathrm{Ba} \\
\left(\mu \mathrm{mol} \mathrm{mol}{ }^{-1}\right)\end{array}$ \\
\hline Paigacha & Aug 97 & 3.6 & 18.1 & 2.3 & 33.3 & 48.0 & 0.4 & 3.5 & 4.3 & 181.4 \\
\hline \multirow[t]{2}{*}{ Khulna } & Jul 96 & 2.7 & 31.9 & 3.8 & 158.6 & 205.8 & 3.1 & 0.5 & 6.0 & 482.1 \\
\hline & May 97 & 2.9 & 33.1 & 4.0 & 124.5 & 200.6 & 2.3 & 0.6 & 6.2 & 453.4 \\
\hline Kuakata & Jul 96 & 2.6 & 34.6 & 4.1 & 3.8 & 99.0 & 0.1 & 2.7 & 6.7 & 177.5 \\
\hline Rajshahi & Aug 97 & 4.4 & 0.3 & 0.4 & 305.0 & 40.0 & 5.7 & 7.7 & 1.3 & 664.6 \\
\hline Gaibandha & Aug 97 & 8.9 & 0.3 & 0.6 & 724.3 & 20.0 & 9.4 & 1.6 & 1.6 & 1047.6 \\
\hline \multirow[t]{3}{*}{ Goalando } & Jul 96 & 1.4 & 1.5 & 1.0 & 166.2 & 12.7 & 4.8 & 2.0 & 3.1 & 480.9 \\
\hline & Oct 96 & 8.9 & 0.2 & 0.5 & 423.1 & 20.0 & 6.9 & 19.3 & 1.6 & 731.4 \\
\hline & May 97 & 5.0 & 1.5 & 0.7 & 117.2 & 34.6 & 2.3 & 19.8 & 2.4 & 590.4 \\
\hline Bhairob Bazar & Aug 97 & 8.8 & 1.3 & 0.7 & 278.4 & 5.2 & 5.9 & 1.4 & 2.2 & 780.1 \\
\hline Sylhet & May 99 & 5.0 & 1.7 & 1.1 & 638.8 & 6.1 & 10.4 & 1.2 & 2.9 & 964.6 \\
\hline \multirow[t]{3}{*}{ Chandpur } & Jul 96 & 8.6 & 3.3 & 0.7 & 63.2 & 20.2 & 1.1 & 52.7 & 2.0 & 433.4 \\
\hline & Oct 96 & 5.6 & 0.7 & 0.5 & 26.1 & 31.0 & 0.7 & 1.5 & 1.8 & 282.7 \\
\hline & May 97 & 9.5 & 0.7 & 0.4 & 62.0 & 18.3 & 0.8 & 17.7 & 1.8 & 318.9 \\
\hline \multirow[t]{2}{*}{ Ramgoti } & Jul 96 & 3.5 & 18.7 & 2.4 & 22.6 & 49.0 & 0.4 & 8.1 & 4.4 & 236.5 \\
\hline & Feb 99 & 3.6 & 18.8 & 2.4 & 16.0 & 49.0 & 0.3 & 0.6 & 4.3 & 180.0 \\
\hline Chittagong & May 97 & 3.8 & 44.1 & 5.3 & 165.5 & 250.3 & 2.9 & 1.1 & 7.9 & 132.4 \\
\hline Cox's Bazar & Jul 96 & 3.0 & 47.4 & 5.6 & 2.1 & 363.0 & 0.02 & 0.6 & 8.3 & 32.2 \\
\hline
\end{tabular}

Water concentrations of the 8 elements examined varied greatly, both between and within sites (Table 2). Most of the differences between sites appear to be related to the degree of mixing of fresh and marine waters. Coastal sites such as Chittagong, Cox's Bazar, Kuakata and Khulna had concentrations of these trace metals that were similar to those of marine waters. Seasonal and interannual differences in concentration of 
Table 3. Mean [metal:Ca] ratio \pm SE of 8 trace metals in the core of hilsa otoliths collected in 1996 from Bangladesh

\begin{tabular}{|c|c|c|c|c|c|c|c|c|c|c|}
\hline Site & Date & $\mathrm{n}$ & $\begin{array}{c}\mathrm{Li} \\
\left(\mu \mathrm{mol} \mathrm{mol}^{-1}\right)\end{array}$ & $\begin{array}{c}\mathrm{Na} \\
\left(\mathrm{mmol} \mathrm{mol}^{-1}\right)\end{array}$ & $\begin{array}{c}\mathrm{Mg} \\
\left(\mathrm{mmol} \mathrm{mol}^{-1}\right)\end{array}$ & $\begin{array}{c}\mathrm{Al} \\
\left(\mu \mathrm{mol} \mathrm{mol}{ }^{-1}\right)\end{array}$ & $\underset{\left(\mu \mathrm{mol} \mathrm{mol}{ }^{-1}\right)}{\mathrm{Mn}}$ & $\begin{array}{c}\mathrm{Zn} \\
\left(\mu \mathrm{mol} \mathrm{mol}{ }^{-1}\right)\end{array}$ & $\begin{array}{c}\mathrm{Sr} \\
\left(\mathrm{mmol} \mathrm{mol}^{-1}\right)\end{array}$ & $\begin{array}{c}\mathrm{Ba} \\
\left(\mu \mathrm{mol} \mathrm{mol}{ }^{-1}\right)\end{array}$ \\
\hline Chandpur & Jul & 10 & $24.1 \pm 5.1$ & $10.9 \pm 0.6$ & $0.20 \pm 0.06$ & $30.4 \pm 7.5$ & $18.8 \pm 2.9$ & $15.7 \pm 4.3$ & $1.37 \pm 0.28$ & $49.7 \pm 23.5$ \\
\hline & Oct & 9 & $17.2 \pm 2.5$ & $10.2 \pm 0.5$ & $0.43 \pm 0.10$ & $163.8 \pm 45.2$ & $12.7 \pm 1.1$ & $10.9 \pm 0.8$ & $1.25 \pm 0.25$ & $15.0 \pm 1.2$ \\
\hline Cox's Bazar & Jul & 12 & $26.8 \pm 7.1$ & $11.3 \pm 0.8$ & $0.15 \pm 0.02$ & $22.4 \pm 2.5$ & $22.5 \pm 6.3$ & $12.6 \pm 1.9$ & $2.20 \pm 0.20$ & $21.5 \pm 5.4$ \\
\hline Goalando & $\begin{array}{l}\text { Jul } \\
\text { Oct }\end{array}$ & $\begin{array}{l}9 \\
9\end{array}$ & $\begin{array}{l}24.1 \pm 4.6 \\
17.8 \pm 1.9\end{array}$ & $\begin{array}{l}12.3 \pm 0.8 \\
11.3 \pm 0.5\end{array}$ & $\begin{array}{l}0.16 \pm 0.02 \\
0.24 \pm 0.04\end{array}$ & $\begin{array}{l}33.0 \pm 8.6 \\
67.0 \pm 10.2\end{array}$ & $\begin{array}{l}13.0 \pm 1.9 \\
11.3 \pm 2.6\end{array}$ & $\begin{array}{l}16.1 \pm 3.7 \\
10.5 \pm 0.4\end{array}$ & $\begin{array}{l}1.21 \pm 0.26 \\
1.02 \pm 0.23\end{array}$ & $\begin{array}{l}19.2 \pm 2.3 \\
10.8 \pm 1.4\end{array}$ \\
\hline Khulna & Jul & 7 & $11.3 \pm 0.8$ & $11.5 \pm 0.3$ & $0.19 \pm 0.04$ & $58.5 \pm 40.2$ & $8.8 \pm 1.6$ & $6.2 \pm 1.4$ & $1.06 \pm 0.22$ & $8.6 \pm 1.5$ \\
\hline Kuakata & Jul & 9 & $18.8 \pm 1.5$ & $11.3 \pm 0.4$ & $0.34 \pm 0.07$ & $71.5 \pm 15.1$ & $12.0 \pm 1.2$ & $10.2 \pm 1.4$ & $0.86 \pm 0.11$ & $11.2 \pm 1.8$ \\
\hline Ramgoti & Jul & 7 & $11.3 \pm 1.1$ & $11.3 \pm 0.6$ & $0.28 \pm 0.14$ & $102.1 \pm 51.8$ & $17.4 \pm 0.5$ & $4.8 \pm 0.8$ & $0.94 \pm 0.16$ & $19.4 \pm 5.7$ \\
\hline
\end{tabular}

some elements between samples at Chandpur and Goalando were similar to those among sites sampled at the same time. Ca concentration also varied by over 20 -fold among sites and by 5- to 7 -fold among the freshwater sites.

\section{Repeat sampling}

Of the 5 sites where sampling was repeated, there were only significant differences in the chemical composition of otolith cores at Chandpur (MANOVA: Pillai's Trace $=0.67, F_{8,16}=4.3, \mathrm{p}<0.01$ ) and Khulna (MANOVA: Pillai's Trace $=0.45, F_{8,11}=3.7, \mathrm{p}<0.05$ ). The differences at Chandpur were driven by changes in the concentration of $\mathrm{Al}$ and $\mathrm{Mg}$ between samples (Al: $F_{1,27}=17.2, \mathrm{p}<0.001, \mathrm{Mg}: F_{1,27}=10.9, \mathrm{p}<0.01$ ) and $\mathrm{Zn}$ between years $\left(F_{1,27}=50.8, \mathrm{p}<0.001\right)$, whereas the differences between the 2 samples from Khulna were due to changes in the concentration of $\mathrm{Li}\left(F_{1,18}=\right.$ 9.7, $\mathrm{p}<0.01), \mathrm{Mn}\left(F_{1,18}=6.4, \mathrm{p}<0.05\right)$ and Ba $\left(F_{1,18}=\right.$ 8.8, p < 0.01).

Comparison among the 3 sites sampled repeatedly in 1996-97 (Chandpur, Goalando and Khulna) showed that the otolith elemental composition differed more between years (MANOVA: Pillai's Trace $=0.58, F_{8,63}=$ 10.8, $\mathrm{p}<0.001$ ) than among sites (Pillai's Trace $=0.48$, $\left.F_{16,128}=2.7, \mathrm{p}<0.01\right)$. Significant differences among sites were found for the mean concentration of $\mathrm{Li}, \mathrm{Mn}$, $\mathrm{Zn}$ and $\mathrm{Ba}(\mathrm{p}<0.05)$. Li and Zn concentrations also varied highly significantly between years $(p<0.001)$ and the site $\times$ year interaction was significant for $\mathrm{Mn}$ and Zn $(\mathrm{p}<0.01)$.

\section{Bangladesh}

1996

There was significant variation among samples collected from 6 sites in Bangladesh in 1996 (MANOVA:
Pillai's Trace $=1.4, F_{40,305}=2.98, \mathrm{p}<0.0001$, Table 3) . The mean concentration of 4 elements differed among sites ( $\mathrm{Li}, \mathrm{Al}, \mathrm{Zn}$ and $\mathrm{Sr}$ ) (all p < 0.01). Neither sex nor otolith weight explained significant amounts of the variation among samples for any of these elements ( $p>$ 0.13). Canonical discriminant function analysis showed that sites grouped into marine (Cox's Bazar), coastal (Ramgoti and Khulna) and riverine sites (Fig. 2). This is consistent with the major differences in water chemistry between these habitats (Table 2). The first 2 functions explained $79 \%$ of the variation between sites (Table 4) and there were significant differences among the mean values of sites on these functions (ANCOVA

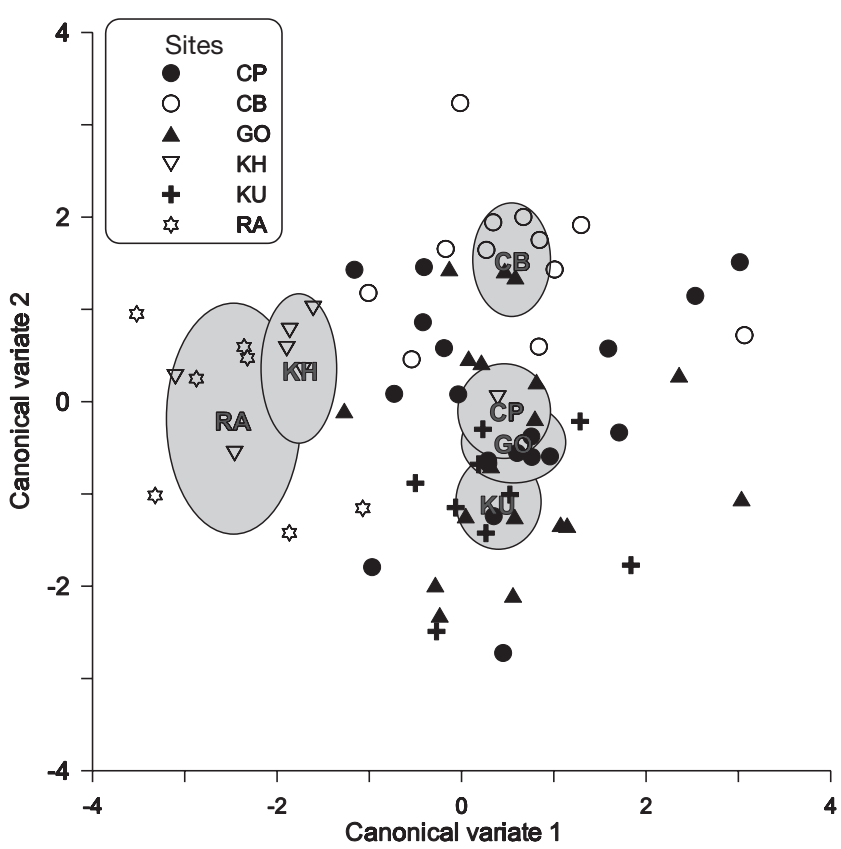

Fig. 2. Plot of the first 2 canonical variates (explaining $79 \%$ of the variation) of trace elements in the core of otoliths of hilsa collected at 6 sites within Bangladesh during 1996. Ellipses represent bootstrapped $95 \%$ confidence regions for each site. $(\mathrm{CP}=$ Chandpur May and October 1996 grouped $\mathrm{CB}=\mathrm{Cox}$ 's Bazar $; \mathrm{GO}=$ Goalando May and October 1996 grouped; KH = Khulna; KU = Kuakata; RA = Ramgoti July 1996) 
Table 4. Standardised canonical discriminant coefficients of 8 trace metals for the first 2 CDFs that explained significantly amounts of the variation in the 3 comparisons shown below $(\mathrm{p}<0.001)$. The first two comparisons are among Bangladesh samples and the comparison between countries includes Bangladesh samples grouped into distinct regions (see Figs 2 \& 3 ) as well as all samples from other countries. The amount of variation explained by each CV in each comparison is shown in parentheses

\begin{tabular}{|c|c|c|c|c|c|c|c|c|}
\hline \multirow[t]{2}{*}{ Element } & \multicolumn{2}{|c|}{ Between 1996 samples } & \multicolumn{2}{|c|}{ Between 1997 samples } & \multicolumn{2}{|c|}{ Between all Bangladesh } & \multicolumn{2}{|c|}{ Between countries } \\
\hline & $\begin{array}{c}\text { CV } 1 \\
(51)\end{array}$ & $\begin{array}{l}\text { CV } 2 \\
\text { (28) }\end{array}$ & $\begin{array}{c}\text { CV } 1 \\
(49)\end{array}$ & $\begin{array}{l}\text { CV } 2 \\
\text { (29) }\end{array}$ & $\begin{array}{c}\text { CV } 1 \\
\text { (53) }\end{array}$ & $\begin{array}{l}\text { CV } 2 \\
(20)\end{array}$ & $\begin{array}{c}\text { CV } 1 \\
(61)\end{array}$ & $\begin{array}{c}\text { CV } 2 \\
(25)\end{array}$ \\
\hline${ }^{7} \mathrm{Li}$ & 0.73 & -0.47 & -0.85 & 0.59 & 0.30 & -1.35 & 0.87 & 0.05 \\
\hline${ }^{23} \mathrm{Na}$ & -0.49 & -0.16 & 0.13 & -0.54 & -0.18 & 0.08 & -0.11 & 0.16 \\
\hline${ }^{24} \mathrm{Mg}$ & 0.34 & -0.22 & -0.24 & 0.11 & 0.13 & -0.23 & 0.26 & 0.48 \\
\hline${ }^{27} \mathrm{Al}$ & -0.41 & -0.61 & -0.05 & 0.11 & -0.35 & 0.09 & 0.28 & 0.21 \\
\hline${ }^{55} \mathrm{Mn}$ & -0.00 & 0.19 & 0.33 & 0.74 & 0.13 & -0.21 & -0.05 & -0.15 \\
\hline${ }^{66} \mathrm{Zn}$ & 1.27 & 0.23 & 0.16 & -0.52 & 1.62 & 0.19 & 0.47 & -0.41 \\
\hline${ }^{88} \mathrm{Sr}$ & -0.25 & 1.05 & 0.57 & 0.11 & 0.00 & 0.60 & 0.59 & 0.60 \\
\hline${ }^{138} \mathrm{Ba}$ & -0.34 & -0.03 & 0.67 & 0.13 & -0.20 & 0.21 & 0.57 & 0.14 \\
\hline
\end{tabular}

$\mathrm{p}<0.001)$. Li and $\mathrm{Zn}$ had the highest positive coefficients on CV 1, whereas $\mathrm{Al}$ and $\mathrm{Sr}$ had high coefficients on CV 2. The Cox's Bazar sample had high values for CV 2, for which Sr had a positive coefficient (Table 4). Otolith weight was not significant on either function $(p>0.4)$.

1997

There were significant differences in the mean concentration of $\mathrm{Li}, \mathrm{Na}, \mathrm{Mn}, \mathrm{Zn}, \mathrm{Sr}$ and $\mathrm{Ba}$ among samples collected from 8 sites in Bangladesh in 1997 (all p < 0.05 ; Table 5). There was no significant effect of sex or otolith weight for any element ( $p>0.19)$. When these data were analysed by canonical discriminant analysis (CDA), there were significant differences among the mean variate values of each site for CVs 1 and 2 ( p < 0.001 ). The first 2 variates explained $78 \%$ of the overall variation and sex and otolith weight were not significant ( $p>0.16)$. Li and $\mathrm{Ba}$ had the largest effect on CV 1 and Li, Na, Mn and Zn on CV 2 (Table 4).

The patterns among sites differed for sites sampled in 1996 (Fig. 3). Riverine sites sampled in 1996 and 1997 (Chandpur and Goalando) were distinct and each grouped with coastal sites whose elemental composition were similar (Table 5). Riverine samples from northwestern Bangladesh were also similar, but separated from the Bhairob Bazar sample collected in northeastern Bangladesh (Fig. 3). Fish from Bhairob Bazar had higher Ba and lower Li in their otoliths than the other inland sites (Table 5), which is reflected in the higher coefficients of these elements on $\mathrm{CV} 1$ (Table 4).

\section{All Bangladesh samples combined}

The analysis of hilsa collected from sites in Bangladesh in 1996 and 1997 revealed 3 site-groups in each analysis (Figs 2 \& 3). These site-groups were analysed in a combined analysis of all fish caught in Bangladesh (Fig. 4). This included additional samples collected from Ramgoti and Sylhet in 1999. These analyses showed that there were 3 overall site-groupings among all the Bangladeshi hilsa samples (Fig. 4) and that the variation in CV 1 and CV 2 was mostly explained by Zn and Li respectively (Table 4). Most of the samples collected in 1997 grouped together with the coastal samples from 1996. The other samples from

Table 5. Mean [metal:Ca] ratio \pm SE of 8 trace metals in the core of otoliths of hilsa collected from Bangladesh in 1997

\begin{tabular}{|c|c|c|c|c|c|c|c|c|c|c|}
\hline Site & Date & $\mathrm{n}$ & $\begin{array}{c}\mathrm{Li} \\
\left(\mu \mathrm{mol} \mathrm{mol}^{-1}\right)\end{array}$ & $\begin{array}{c}\mathrm{Na} \\
\left(\mathrm{mmol} \mathrm{mol}^{-1}\right)\end{array}$ & $\begin{array}{c}\mathrm{Mg} \\
\left(\mathrm{mmol} \mathrm{mol}^{-1}\right)\end{array}$ & $\begin{array}{c}\mathrm{Al} \\
\left(\mu \mathrm{mol} \mathrm{mol}{ }^{-1}\right)\end{array}$ & $\begin{array}{c}\mathrm{Mn} \\
\left(\mu \mathrm{mol} \mathrm{mol}^{-1}\right)\end{array}$ & $\underset{(\mu \mathrm{mol} \mathrm{mol}}{\mathrm{Zn}})$ & $\begin{array}{c}\mathrm{Sr} \\
\left(\mathrm{mmol} \mathrm{mol}^{-1}\right)\end{array}$ & $\begin{array}{c}\mathrm{Ba} \\
\left(\mu \mathrm{mol} \mathrm{mol}{ }^{-1}\right)\end{array}$ \\
\hline Bhairob Bazar & Aug & 20 & $10.6 \pm 1.1$ & $10.8 \pm 0.2$ & $0.13 \pm 0.01$ & $44.8 \pm 9.3$ & $18.1 \pm 2.3$ & $3.7 \pm 0.2$ & $0.97 \pm 0.07$ & $19.1 \pm 2.3$ \\
\hline Chandpur & May & 9 & $20.3 \pm 1.7$ & $10.7 \pm 0.3$ & $0.19 \pm 0.04$ & $65.1 \pm 21.6$ & $16.0 \pm 2.6$ & $4.5 \pm 0.9$ & $0.96 \pm 0.11$ & $28.9 \pm 9.0$ \\
\hline Chittagong & May & 14 & $21.8 \pm 2.5$ & $10.3 \pm 0.3$ & $0.16 \pm 0.02$ & $33.8 \pm 10.1$ & $7.2 \pm 1.0$ & $3.5 \pm 0.4$ & $0.86 \pm 0.13$ & $8.8 \pm 0.7$ \\
\hline Gaibandha & Aug & 20 & $13.4 \pm 1.8$ & $11.1 \pm 0.3$ & $0.17 \pm 0.02$ & $33.9 \pm 5.0$ & $13.4 \pm 2.7$ & $4.4 \pm 0.3$ & $0.75 \pm 0.09$ & $14.4 \pm 1.7$ \\
\hline Goalando & May & 10 & $20.9 \pm 2.6$ & $10.4 \pm 0.3$ & $0.16 \pm 0.02$ & $78.9 \pm 24.6$ & $7.8 \pm 1.2$ & $4.2 \pm 0.7$ & $0.92 \pm 0.10$ & $11.2 \pm 1.2$ \\
\hline Khulna & May & 14 & $19.3 \pm 1.7$ & $10.5 \pm 0.2$ & $0.18 \pm 0.02$ & $66.8 \pm 25.1$ & $22.4 \pm 3.4$ & $4.9 \pm 0.7$ & $0.88 \pm 0.10$ & $17.1 \pm 2.7$ \\
\hline Paigacha & Aug & 19 & $13.3 \pm 1.5$ & $10.9 \pm 0.2$ & $0.14 \pm 0.01$ & $42.1 \pm 10.8$ & $12.1 \pm 1.1$ & $5.5 \pm 0.7$ & $0.85 \pm 0.08$ & $11.6 \pm 1.1$ \\
\hline Rajshahi & Aug & 19 & $14.6 \pm 2.1$ & $11.6 \pm 0.2$ & $0.20 \pm 0.03$ & $54.0 \pm 16.1$ & $11.2 \pm 1.3$ & $5.6 \pm 0.4$ & $0.85 \pm 0.12$ & $13.9 \pm 1.8$ \\
\hline
\end{tabular}




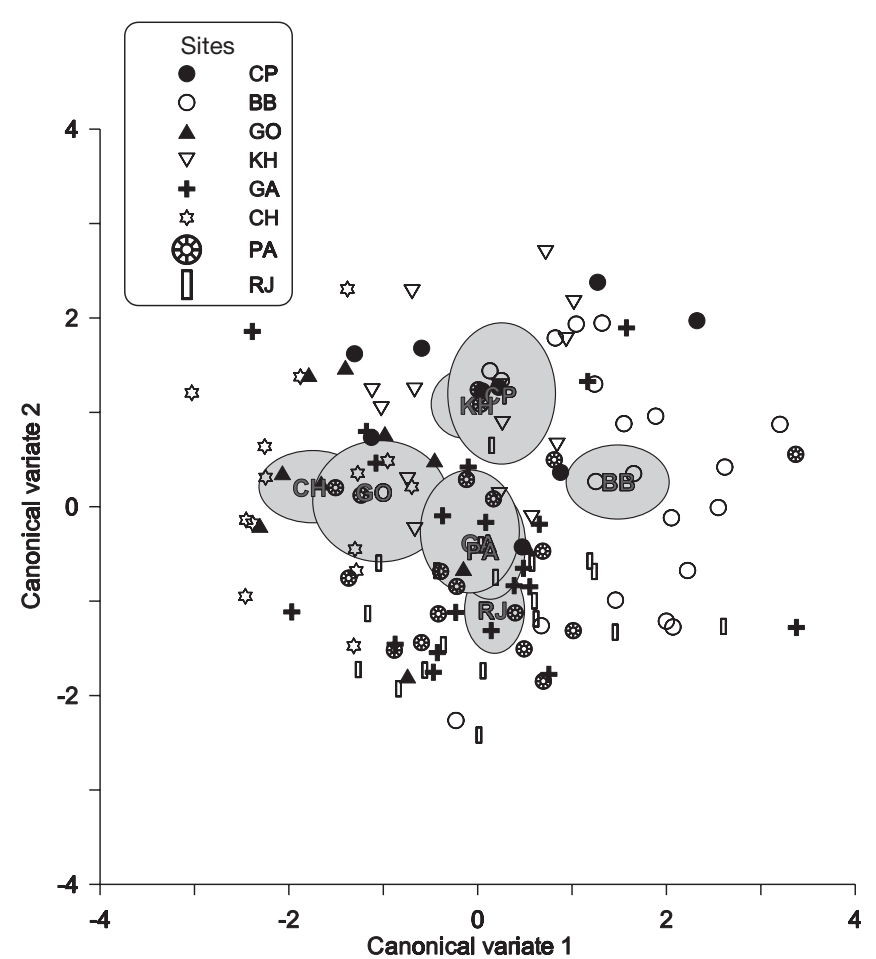

Fig. 3. Plot of the first 2 canonical variates (explaining $78 \%$ of the variation) of trace element composition of the otolith cores of hilsa collected at 8 sites in Bangladesh during 1997 $(\mathrm{CP}=$ Chandpur; $\mathrm{BB}=$ Bhairob Bazar $\mathrm{GO}=$ Goalando; $\mathrm{KH}=$ Khulna $; \mathrm{GA}=$ Gaibandha $; \mathrm{CH}=$ Chittagong; $\mathrm{PA}=$ Paigacha; RJ = Rajshahi). Ellipses represent the bootstrapped 95\% confidence regions.

1996 were statistically different on CV 1 and CV 2. The single sample from Sylhet separated from both other site-groups.

\section{Comparison throughout range}

Samples from Bangladesh collected in 1996 and 1997 were grouped and compared with samples from other parts of the species' range (Table 6). There were no

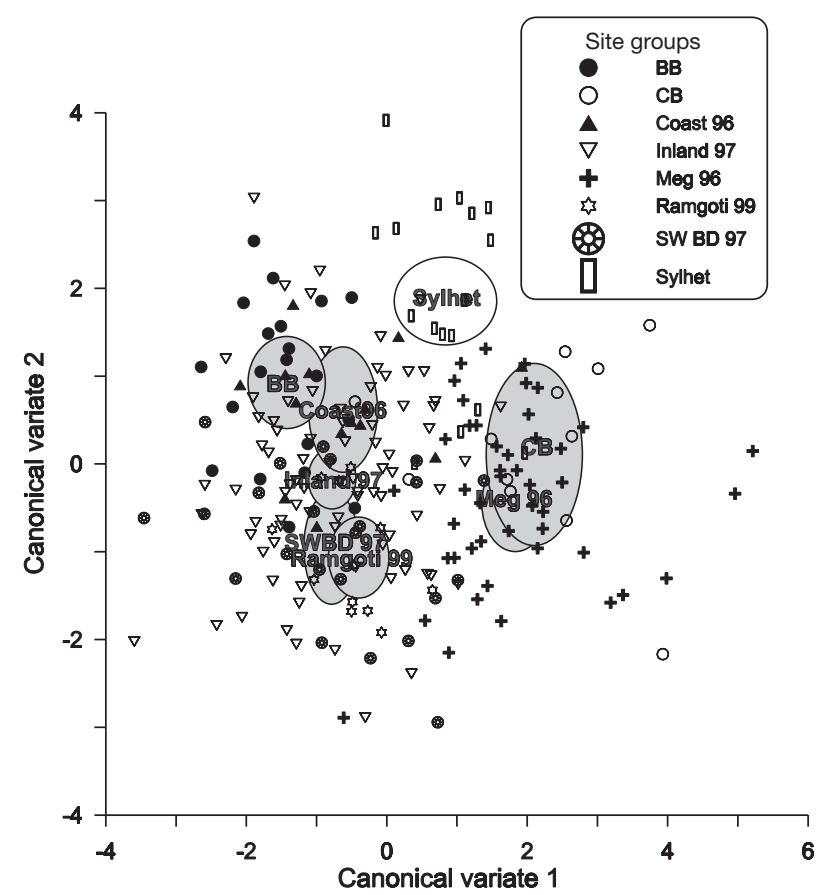

Fig. 4. Plot of the first 2 canonical variates (explaining $83 \%$ of the variation) of trace elemental composition of the core of the otoliths of hilsa from site-groups identified in the analysis of 1996 and 1997 samples from Bangladesh (see Figs 2 \& 3) and samples from Ramgoti and Sylhet collected during 1999. Ellipses represent the bootstrapped $95 \%$ confidence regions of each group. ( $\mathrm{BB}=$ Bhairob Bazar; $\mathrm{CB}=\mathrm{Cox}$ 's Bazar; Coast 96 = Khulna and Ramgoti samples collected in 1996; Inland $97=$ Chittagong, Goalando, Gaibandha, Paigacha and Rajshahi samples collected in 1997; Meg 96 = Chandpur, Goalando and Kuakata samples collected in 1996; Ramgoti $99=$ Ramgoti February 1999; SW BD 97 = Chandpur and Khulna samples collected in 1997; Sylhet = Sylhet May 1999)

significant differences among the 3 samples from northern Sumatra so they were also grouped for the combined analysis.

The MANOVA showed that there were highly significant differences in the elemental composition of otolith cores among countries (Pillai's Trace $=1.1, F_{40,1585}=11.3$, $\mathrm{p}<0.0001)$. All elements differed among countries

Table 6. Mean (metal:Ca ratios \pm SE) of 8 trace metals in the core of otoliths of hilsa collected from Bangladesh (B) in 1998 and 1999 and sites in other countries where hilsa were collected

\begin{tabular}{|c|c|c|c|c|c|c|c|c|c|c|}
\hline Site & Date & $\mathrm{n}$ & $\begin{array}{c}\mathrm{Li} \\
\left(\mu \mathrm{mol} \mathrm{mol}{ }^{-1}\right)\end{array}$ & $\begin{array}{c}\mathrm{Na} \\
\left(\mathrm{mmol} \mathrm{mol}^{-1}\right)\end{array}$ & $\begin{array}{c}\mathrm{Mg} \\
\left(\mathrm{mmol} \mathrm{mol}^{-1}\right)\end{array}$ & $\begin{array}{c}\mathrm{Al} \\
\left(\mu \mathrm{mol} \mathrm{mol}{ }^{-1}\right)\end{array}$ & 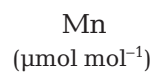 & $\begin{array}{c}\mathrm{Zn} \\
\left(\mu \mathrm{mol} \mathrm{mol}{ }^{-1}\right)\end{array}$ & $\begin{array}{c}\mathrm{Sr} \\
\left(\mathrm{mmol} \mathrm{mol}^{-1}\right)\end{array}$ & $\begin{array}{c}\mathrm{Ba} \\
\left(\mu \mathrm{mol} \mathrm{mol}{ }^{-1}\right)\end{array}$ \\
\hline Kuwait & Jun 96 & 16 & $33.0 \pm 2.6$ & $13.6 \pm 0.4$ & $029 \pm 0.03$ & $58.7 \pm 2.9$ & $10.9 \pm 1.0$ & $5.7 \pm 0.2$ & $2.2 \pm 0.06$ & $6.9 \pm 0.8$ \\
\hline Myanmar & Aug 98 & 28 & $20.9 \pm 1.7$ & $11.1 \pm 0.4$ & $0.40 \pm 0.06$ & $64.2 \pm 8.9$ & $11.3 \pm 2.0$ & $3.9 \pm 0.4$ & $2.3 \pm 0.10$ & $18.2 \pm 1.3$ \\
\hline \multirow[t]{3}{*}{ Sumatra } & Nov 96 & 9 & $72.8 \pm 9.5$ & $10.1 \pm 0.3$ & $0.27 \pm 0.03$ & $104.5 \pm 40.3$ & $8.8 \pm 0.8$ & $10.1 \pm 1.3$ & $2.1 \pm 0.29$ & $5.5 \pm 0.8$ \\
\hline & Apr 97 & 20 & $53.3 \pm 7.2$ & $10.1 \pm 0.2$ & $0.24 \pm 0.01$ & $67.6 \pm 10.5$ & $13.9 \pm 1.1$ & $11.5 \pm 1.0$ & $1.9 \pm 0.10$ & $7.5 \pm 0.7$ \\
\hline & Nov 97 & 8 & $70.8 \pm 7.2$ & $9.3 \pm 0.6$ & $0.17 \pm 0.02$ & $140.3 \pm 48.9$ & $12.1 \pm 1.5$ & $11.6 \pm 0.9$ & $2.1 \pm 0.23$ & $8.2 \pm 2.2$ \\
\hline Ramgoti (B) & Feb 99 & 12 & $29.8 \pm 3.7$ & $12.8 \pm 1.2$ & $0.30 \pm 0.05$ & $52.2 \pm 10.8$ & $9.5 \pm 0.7$ & $4.3 \pm 0.2$ & $1.9 \pm 0.24$ & $17.1 \pm 3.1$ \\
\hline SE India & Aug 98 & 26 & $23.0 \pm 2.3$ & $11.7 \pm 0.4$ & $0.37 \pm 0.05$ & $28.9 \pm 5.1$ & $12.1 \pm 1.8$ & $9.0 \pm 1.5$ & $1.4 \pm 0.1$ & $14.7 \pm 1.2$ \\
\hline Sylhet (B) & May 99 & 17 & $8.8 \pm 1.3$ & $12.4 \pm 0.5$ & $0.37 \pm 0.12$ & $106.2 \pm 22.4$ & $15.6 \pm 2.3$ & $10.0 \pm 0.7$ & $1.1 \pm 0.10$ & $20.5 \pm 2.0$ \\
\hline
\end{tabular}




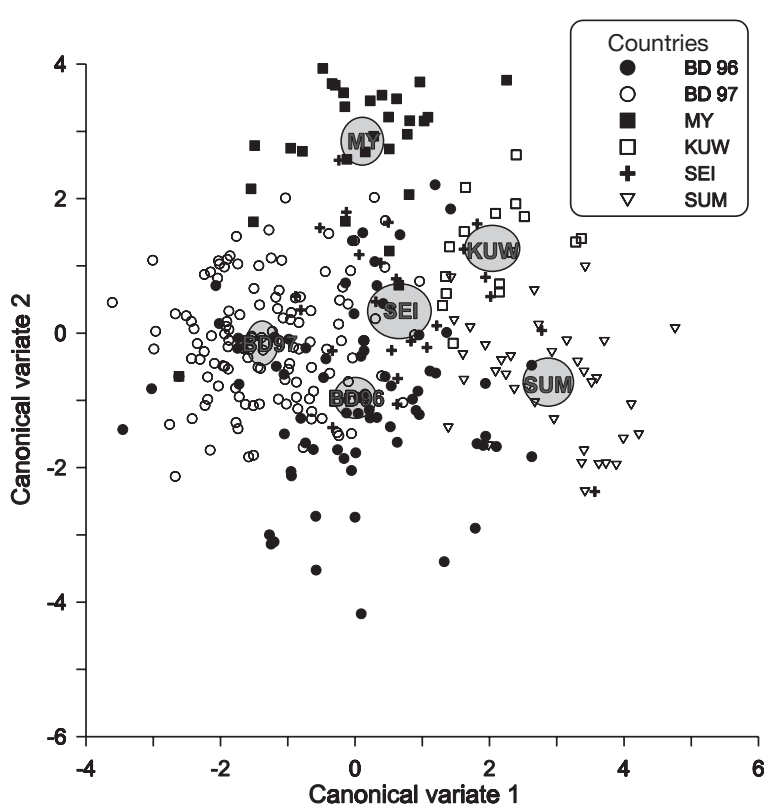

Fig. 5. Plot of the first 2 canonical variates (explaining $78 \%$ of the variation) and the $95 \%$ confidence ellipses of trace element composition of the cores of the cores of otoliths of hilsa collected in 1996 and 1997 from Bangladesh and samples from Myanmar, India, Indonesia and Kuwait. (BD $96=$ Bangladesh 1996 samples; BD 97 = Bangladesh 1997 samples; $\mathrm{MY}=$ Myanmar; KUW = Kuwait; SEI = SE India $;$ SUM = NE Sumatra November 1996, April 1997, and November 1997 grouped)

( $p<0.001)$, except Mn. There was no significant effect of sex or otolith weight for any element, although there was a significant country $\times$ sex interaction for barium $(p<0.01)$. The bootstrapped $95 \%$ confidence ellipses of each sample groups' mean did not overlap on CV 1 and CV 2 (Fig. 5) and these functions explained $85 \%$ of the variation. $\mathrm{Li}, \mathrm{Sr}$ and $\mathrm{Ba}$ had the largest coefficients on CV 1 and Mg and Sr on CV 2 (Table 4).

The cross-validation sample allocation from the discriminant function analysis showed a high degree of accuracy assignment of hilsa in some samples
(Table 7). The classification accuracy varied from $35 \%$ for the Indian sample, to $100 \%$ for those from Indonesia and Kuwait. Fish that were misclassified usually were classified into the geographically closest group. Hilsa collected throughout Bangladesh in 1996 and 1997 were classified accurately $(75 \%)$ and misclassified fish were mostly assigned to the other group. The Indian samples were the fish that were classified with least accuracy. Misclassified fish were either assigned to Bangladesh (53\% of fish) or Myanmar.

\section{DISCUSSION}

The results of our study show that hilsa born in geographically separate areas can be distinguished by differences in the chemical composition in their otoliths. Fish collected from sites outside the Bay of Bengal (Sumatra and Kuwait) had more distinctive otolith chemistry than fish collected from most of the other sites. Hilsa from these other sites are genetically distinct from hilsa in the Bay of Bengal (Hussain et al. 1998, Salini et al unpubl. data).

Within the Bay of Bengal, hilsa from southeastern India and Myanmar could not be genetically separated from fish collected in Bangladesh (Salini et al. unpubl. data). We could not distinguish fish from India, in particular, and they were mostly misclassified as coming from Bangladesh in the discriminant function analysis (DFA). We have no water chemistry data from SE India, but the amount of variation in water chemistry within and among sites in Bangladesh strongly suggests that there should be significant differences.

Most of the differences among our samples from Bangladesh were related to the year in which they were collected (we only examined 1+ yr old fish from Bangladesh) rather than to their coming from geographically separate stocks. Fish caught at several sites in the main Meghna River system up to $500 \mathrm{~km}$ apart within a few days of each other (1997 samples) had

Table 7. Classification of hilsa collected throughout the species' range after linear discriminant function analysis of the elemental composition of the cores of their otoliths. Values indicate crossvalidation accuracy (\%). Samples were from Bangladesh in 1996 (BD 96), 1997 (BD 97) and Sylhet (Sy), Sumatra, Indonesia (ID), Kuwait (KU), Myanmar (MY) and SE India (SEI). Values in bold indicate correct allocation

\begin{tabular}{|c|c|c|c|c|c|c|c|}
\hline Sample source & BD 96 & BD 97 & Sy & ID & KU & MY & SEI \\
\hline Bangladesh 1996 (n = 58) & 57 & 31 & 5 & 0 & 0 & 2 & 5 \\
\hline Bangladesh $1997(\mathrm{n}=151)$ & 18 & 75 & 1 & 0 & 0 & 3 & 3 \\
\hline Sylhet $(n=17)$ & 6 & 35 & 47 & 0 & 0 & 12 & 0 \\
\hline Sumatra $(n=36)$ & 0 & 0 & 0 & 100 & 0 & 0 & 0 \\
\hline Kuwait $(\mathrm{n}=16)$ & 0 & 0 & 0 & 0 & 100 & 0 & 0 \\
\hline Myanmar $(\mathrm{n}=28)$ & 4 & 21 & 0 & 0 & 0 & 75 & 0 \\
\hline SE India $(n=26)$ & 12 & 33 & 8 & 0 & 0 & 12 & 35 \\
\hline
\end{tabular}


similar otolith chemistry despite the [metal:Ca] ratios of some elements in the water differing by 3 to 4 times. This suggests that there must be considerable mixing of hilsa in the Meghna River system.

Hilsa in most other regions are known to migrate (Pillay et al. 1963), mainly to spawn in freshwater during the monsoon season (June to October) and/or in winter (December to February) (Jenkins 1938, Hora 1941, de Graaf et al. 1999). Our results confirm this pattern among hilsa in the Meghna River. The otolith Sr concentration of fish collected in Bangladesh shows that hilsa collected in fresh and coastal waters spawn in waters with a range of Sr concentrations (and salinities) (Secor et al. 1995), and a small proportion spawn in the sea (Fig. 6). In addition, fish caught in the middle reaches (Goalando) can have similar otolith chemistry to fish collected on the coast (Khulna) in one sample, but be similar to fish collected offshore of the river mouth or the lower reaches (Chandpur, Chittagong) in another. These patterns are consistent with the results of genetic studies of the same fish that showed no genetic differences among the Bangladesh samples (Hussain et al. 1998).

This pattern did not hold for one sample-Sylhet. This site is in the extreme northeastern part of Bangladesh. These fish differed from their nearest sample (Bhairob Bazar) in the concentration of 4 ele-

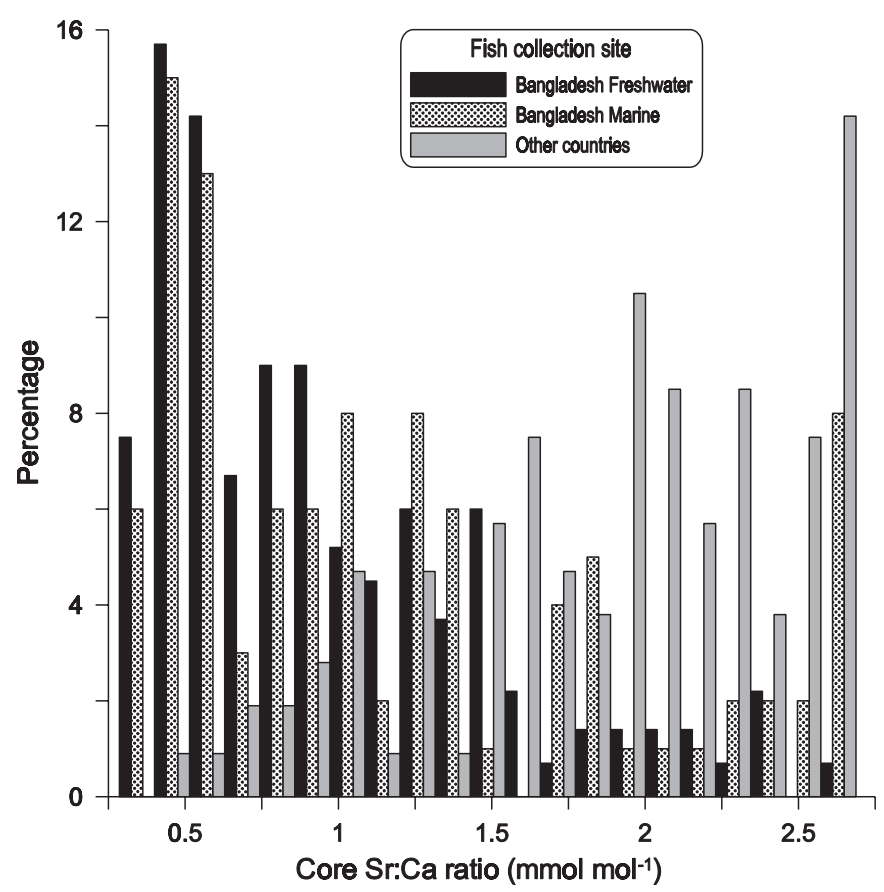

Fig. 6. Percentage frequency distribution of Sr concentration $\left(\mu \mathrm{g} \mathrm{g}^{-1}\right)$ in the core of hilsa otoliths collected from fish caught in freshwater in Bangladesh (>150 km inland from the coast), marine (coastal and marine fish landed in Bangladesh) and fish collected from other countries ments ( $\mathrm{Mg}, \mathrm{Al}, \mathrm{Zn}$ and $\mathrm{Ba})$. The Bhairob Bazar sample was collected 2 yr previously, so these differences could reflect interannual fluctuations in water chemistry or they could support the local fishers' belief that their hilsa are resident and do not migrate (unlike hilsa in other parts of Bangladesh are believed to do) (Rahman \& Moula 1992). The genetic and morphometric data for this site conflict: the morphometric results showed a high level of discrimination for the Sylhet sample (20 of 27 fish correctly classified, Salini et al. unpubl. data) but no genetic separation from elsewhere in Bangladesh. Given the low genetic variation found by Hussain et al. (1998) and the extreme morphometric variability in clupeoids, all these data (genetics, otolith chemistry and morphometrics) suggest that if there is limited exchange with fish in this region, it is probably a relatively recent event. Hilsa in the most inland parts of their range in the middle Ganges River are also believed to be resident (Ghosh et al. 1968, Ghosh \& Nangpal 1970).

Morphometric studies (Quddus et al. 1984a, Rahman \& Moula 1992, Rahman et al. 1997) suggest that between 2 and 4 forms or 'stocks' of hilsa occur in the Meghna River system in Bangladesh — 'broad' and 'slender' (Quddus et al. 1984 a) — or 4 broadly overlapping stocks (Rahman \& Moula 1992, Rahman et al. 1997). The 'broad' and 'slender' stocks co-occur, but grow at different rates and spawn in different seasons at the same sites (Quddus et al. 1984b,c).

High levels of morphological variation among samples collected within a small geographic region have been found in many other clupeoids (e.g. Ryman et al. 1984, Smith \& Jamieson 1986, Hedgecock et al. 1989, Kinsey et al. 1994, Tudela 1999). None of these studies found any evidence of genetic differences among their samples. They all concluded that the observed morphological variation either reflected phenotypic plasticity or environmental influences (Swain \& Foote 1999). Our genetic and morphological studies will be reported separately (Salini et al. unpubl. data). However, we found that the morphology of Bangladeshi hilsa varied both regionally and interannually at the same site in a similar manner to the otolith microchemistry.

While the detection of such complex stock structure may be desirable (Stephenson 1999), and our studies of otolith microchemistry suggest that some fine-scale discrimination of spawning areas in Bangladesh is possible, this level of discrimination is unlikely to be of practical value for hilsa management. Our data show that any stock structuring in the Meghna River in Bangladesh detected by otolith chemistry is not stable over time, as schools of fish that have spawned throughout the country (Blaber et al. 1998) mix and move seasonally. 
The hilsa fishery in Bangladesh is not actively managed at present; it would be difficult to introduce any management measures to conserve co-occurring stocks, given the estimated 2 million fishers (Blaber et al. 1998) and the 16000 fishing vessels throughout the country (Blaber 1997). Dahle et al. (1997) separated fish from 3 sites within $150 \mathrm{~km}$ of each other (Chandpur, Kuakata-Khulna region and Cox's Bazar) (Fig. 1) with RAPD fingerprinting, implying separate populations (stocks).

Our sample from Cox's Bazar separated from fish at other sites sampled at the same time, but had very similar composition to those from Myanmar, India and nearby coastal areas of Bangladesh. Hussain et al. (1998) found no evidence of different Bangladeshi stocks, including samples from these same sites. Dahle et al. (1997) admitted that the difficulty in duplicating RAPD results and their uncertain heritability makes this method the least useful DNA method for detecting stock structure (Dowling et al. 1996). This must cast doubt on the genetic basis of their findings, given the short distances between sites. Our evidence of similar otolith chemistry among fish from a greater range of sites that differ in water chemistry also argues against the likelihood of more than one stock in this small region.

This study provides some encouraging evidence that there may be a close correlation among stock structures derived from complementary genetic and otolith microchemistry data (Fig. 7). However, the evi-
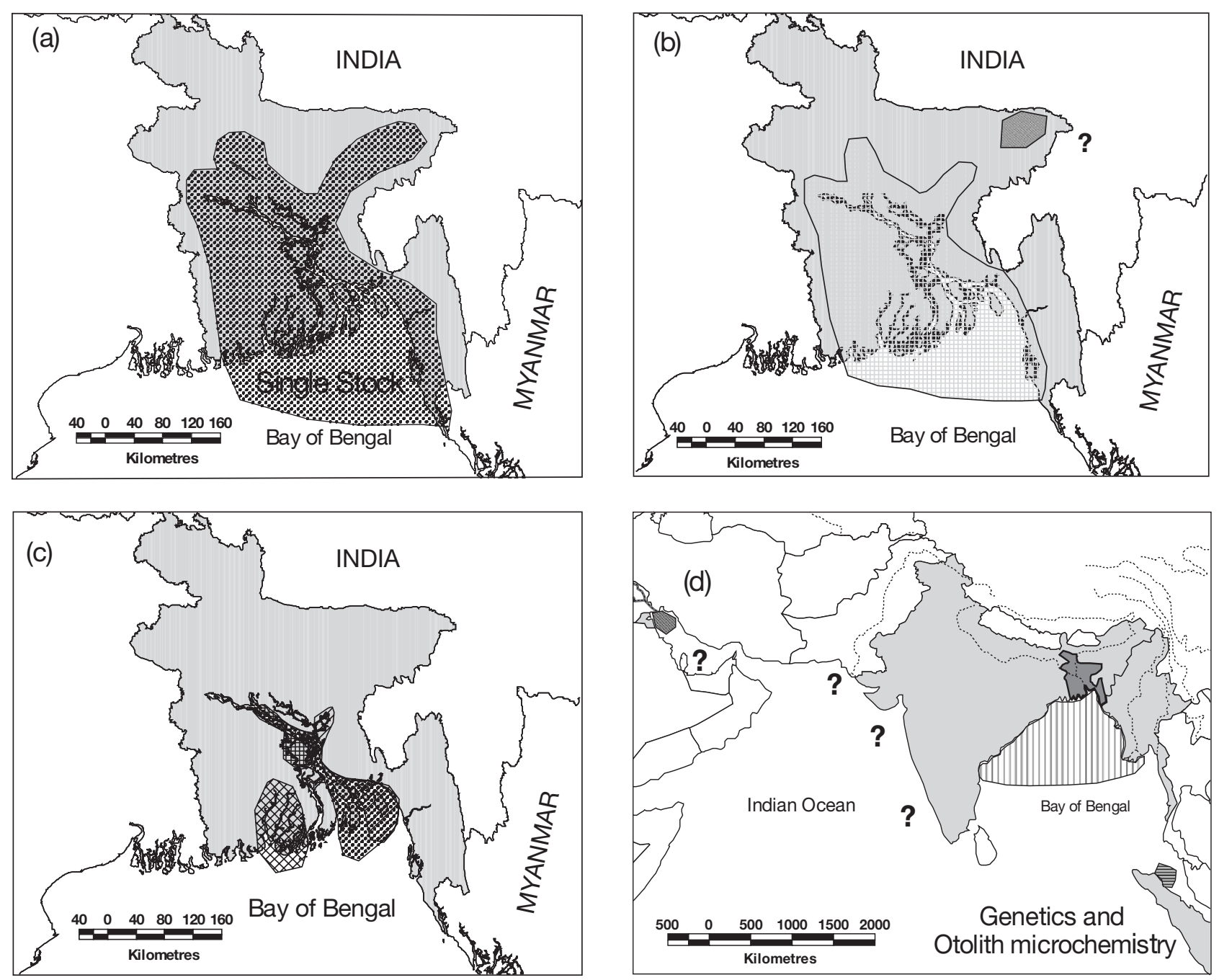

Fig. 7. Summary of the stock structure of hilsa in Bangladesh based on (a) allozymes (Hussain et al. 1998), (b) otolith microchemistry of fish examined during this study and (c) morphometric studies by Rahman \& Moula (1992) and Rahman et al. (1997). (d) The overall stock structure throughout the species' range identified by both genetics and otolith microchemistry is also shown. Countries where samples were collected during the study are shaded; different hatchings represent the stocks identified by each method 
dence supporting the use of otolith chemistry to detect stock structure is weak as both the genetic and otolith chemistry failed to reject the null hypothesis that there is no population structure. In this situation, some population structuring may exist, but was not detected. Alternatively, the similarities in the otolith composition at several sites are due to similarities in water chemistry. Our water chemistry data showed quite large differences among samples, making this alternative less likely.

Rather, the extensive knowledge of hilsa life history and migratory patterns (Jafri \& Melvin 1988) suggests that the results from our study largely agree with the pattern that one would intuitively expect in Bangladesh. While there may be groups of fish that may have different migratory patterns (Fig. 7) (Quddus et al. 1984a, Rahman et al. 1997), these groups intermingle during at least part of the year and cannot be reliably separated and managed as such. Thus, the population of hilsa in Bangladesh should effectively be treated as a single stock for management purposes.

Our study also highlights the temporal variability in otolith chemistry (Edmonds et al. 1992, Milton et al. 1997, Dove \& Kingsford 1998) and the unlikelihood of repeating the results obtained from samples taken during a single sampling period. This further reduces the credibility of otolith composition as a reliable stock discriminator (Campana 1999, Thresher 1999, Campana et al. 2000). It suggests that the technique may be better at providing a fingerprint of spawning or nursery areas (Thresher et al. 1994) that can be recognised among fish mixing during the non-breeding season (Campana et al. 2000). This would have greater application in migratory species such as salmonids as fish spawning in different areas may also be genetically isolated from each other. Other applications would depend on the life cycle of the species being studied.

In conclusion, we have shown that there is an environmental component to the variability in the chemical composition of otoliths of hilsa from Bangladesh. Patterns of variation in otolith composition differed between repeat samples from the same sites, supporting the large number of previous studies of hilsa that conclude these fish are highly migratory. Samples of fish caught in fresh or marine waters could be a mixture from those and other areas. Some of this variation in otolith chemistry correlated with allozyme patterns in the same fish. Hilsa from genetically distinct locations (Kuwait and Sumatra) could also be separated by their otolith composition. These results show that, provided water chemistry differs between sites, otolith composition can separate populations that are genetically distinct, but cannot be used in isolation to detect them with any reliability.
Acknowledgements. We thank our colleagues Steve Blaber, David Brewer, John Salini, and Anisur Rahman for help with fish collection, and Tonya van der Velde for sample preparation. Craig Proctor, John Gunn and 4 anonymous referees gave helpful comments that improved earlier drafts of the manuscript. This project was partly funded by the Australian Council for International Agricultural Research (ACIAR Project No. 9430).

\section{LITERATURE CITED}

Blaber SJM (1997) Fish and fisheries of tropical estuaries. Chapman \& Hall, London

Blaber SJM, Mazid MA, Milton DA, Salini JP, Rawlinson NJF (1998) The BFRI-CSIRO collaborative research project on hilsa in Bangladesh: a progress report (1996-1997). In: Mazid MA, Blaber SJM (eds) Hilsa fisheries research in Bangladesh. Bangladesh Fish Res Inst (BFRI) Proc 6:43-53

Booke HE (1981) The conundrum of the stock concept-are nature and nurture definable in fisheries science? Can J Fish Aquat Sci 38:1479-1480

Booke HE (1999) The stock concept revisited: perspectives on its history in fisheries. Fish Res 43:9-11

Campana SE (1999) Chemistry and composition of fish otoliths: pathways, mechanisms and applications. Mar Ecol Prog Ser 188:263-297

Campana SE, Fowler AJ, Jones CM (1994) Otolith elemental fingerprinting for stock identification of Atlantic cod (Gadus morhua) using laser ablation ICPMS. Can J Fish Aquat Sci 51:1942-1950

Campana SE, Chouinard GA, Hanson JM, Frechet A, Brattey $\mathrm{J}$ (2000) Otolith elemental fingerprints as biological tracers of fish stocks. Fish Res 46:343-357

Chenery S, Cook JM (1993) Determination of rare earth elements in single mineral grains by laser ablation microprobe-inductively coupled plasma mass spectrometry. J Anal Atomic Spect 8:299-303

Cushing DH (1968) Fisheries biology - a study in population dynamics. University of Wisconsin Press, Madison

Dahle G, Rahman M, Eriksen AG (1997) RADP fingerprinting used for discriminating among three populations of hilsa shad (Tenualosa ilisha). Fish Res 32:263-269

de Graaf GJ, Born AF, Uddin AMK, Huda S (1999) Larval fish movement in the River Lohajang, Tangail, Bangladesh. Fish Manag Ecol 6:109-120

Dove SG, Kingsford MJ (1998) Use of otoliths and eye lenses for measuring trace-metal incorporation in fishes: a biogeographic study. Mar Biol 130:377-387

Dowling TE, Moritz C, Palmer JD, Rieseberg LH (1996) Nucleic acids III: Analysis of fragments and restriction sites. In: Hillis DM, Moritz C, Mable BK (eds) Molecular systematics, 2nd edn. Sinauer Associates, Sunderland, p 249-320

Edmonds JS, Lenanton RCJ, Caputi N, Morita M (1992) Trace elements in the otoliths of yellow-eye mullet (Aldrichetta forsteri) as an aid to stock identification. Fish Res 13:39-51

FAO (1995) Fisheries statistics. FAO, Rome

Ghosh AN, Nangpal TD (1970) On the winter breeding of Hilsa ilisha in the Ganges River system. Proc Ind Pac Fish Coun 13:132-142

Ghosh AN, Bhattacharya RK, Rao KV (1968) On the identification of the sub-populations of Hilsa ilisha in the Gangetic system with a note on their distribution. Proc Natl Inst Sci India 34B:44-59

Hedgecock D, Hutchinson ES, Li G, Sly FL, Nelson K (1989) Genetic and morphological variation in the Pacific sar- 
dine, Sardinops sagax caerulea: comparisons and contrasts with historical data and variability in the northern anchovy, Engraulis mordax. Fish Bull US 87:653-671

Hora SL (1941) Life-history and wanderings of hilsa in Bengal waters. J Asiatic Soc Bengal 6:93-112

Hussain MG, Salini JP, Islam MS, Mazid MA (1998) Genetic structure of hilsa shad populations: preliminary results using starch gel allozymes. In: Mazid MA, Blaber SJM (eds) Hilsa fisheries research in Bangladesh. Bangladesh Fish Res Inst (BFRI) Proc 6:37-42

Jafri SIH, Melvin GD (1988) Annotated bibliography (1803-1987) of the Indian shad Tenualosa ilisha (Teleostei: Clupeidae). IDRC Rep 178

Jenkins JT (1938) Spawning of hilsa. Current Sci 9:241-242

Kinsey ST, Orsoy T, Bert TM, Mahmoudi B (1994) Population structure of the Spanish sardine Sardinella aurita: natural morphological variation in a genetically homogeneous population. Mar Biol 118:309-317

Kutkuhn JH (1981) Stock definition as a necessary basis for cooperative management of Great Lake fish resources. Can J Fish Aquat Sci 38:1476-1478

Milton DA, Chenery SR (1998) The effect of otolith storage methods on the concentrations of elements detected by laser-ablation ICPMS. J Fish Biol 53:785-794

Milton DA, Chenery SR, Farmer MJ, Blaber SJM (1997) Identifying the spawning estuaries of the tropical shad, terubok Tenualosa toli, using otolith microchemistry. Mar Ecol Prog Ser 153:283-291

Morrison DF (1976) Multivariate statistical methods. McGraw-Hill, New York

Pillay TVR (1957) A morphometric study of the populations of hilsa Hilsa ilisha of the river Hoogly and Chilka Lake. Ind J Fish 4:344-386

Pillay TVR, Rao KV, Mathur PK (1963) Preliminary report on the tagging of the hilsa Hilsa ilisha. Proc Indo-Pac Fish Coun 10:28-36

Proctor CH, Thresher RE (1998) Effects of specimen handling and otolith preparation on concentration of elements in fish otoliths. Mar Biol 131:681-694

Quddus MMA, Shimizu M, Nose Y (1984a) Meristic and morphometric differences between two types of Hilsa ilisha in Bangladesh waters. Bull Jpn Soc Sci Fish 50:43-49

Quddus MMA, Shimizu M, Nose Y (1984b) Comparison of age and growth of two types of Hilsa ilisha in Bangladesh waters. Bull Jpn Soc Sci Fish 50:51-57

Quddus MMA, Shimizu M, Nose Y (1984c) Spawning and fecundity of two types of Hilsa ilisha in Bangladesh waters. Bull Jpn Soc Sci Fish 50:177-181

Querol X, Chenery S (1995) Determination of trace element affinities in coal by laser ablation microprobe-inductively

Editorial responsibility: Otto Kinne (Editor),

Oldendorf/Luhe, Germany coupled plasma mass spectrometray. In: Whately MK, Spears DA (eds) European coal geology. Geol Soc Spec Publ No. 82, London, p 147-155

Rahman MJ, Moula G (1992) Management-oriented research on the hilsa fisheries of Bangladesh. Naga 15:34-35

Rahman MA, Miah MS, Rahman MJ, Haldar GC, Mazid MA (1997) Application of biometric and electrophoretic methods for the stock discrimination of hilsa (Tenualosa ilisha) in Bangladesh waters. Indian J Anim Sci 67:1024-1027

Ryman N, Lagercrantz U, Andersonn L, Chakraborty $\mathrm{R}_{1}$ Rosenberg R (1984) Lack of correspondence between genetic and morphological variability patterns in Atlantic herring (Clupea harengus). Heredity 53:687-704

SAS (1989) SAS/STAT user guide, Ver 6, 4th edn. SAS Institute Inc. Cary, NC

Secor DH, Henderson-Arzapalo A, Piccoli PM (1995) Can otolith microchemistry chart patterns of migration and habitat utilisation in anadromous fishes? J Exp Mar Biol Ecol 192:15-33

Smith PJ, Jamieson A (1986) Stock discreteness in herring: a conceptual revolution. Fish Res 4:223-234

Smith PJ, Jamieson A, Birley AJ (1990) Electrophoretic studies and the stock concept in marine teleosts. J Cons Int Explor Mer 47:231-245

Stephenson RL (1999) Stock complexity and fisheries management: a perspective of emerging issues related to population sub-units. Fish Res 43:247-249

Swain DP, Foote CJ (1999) Stocks and chameleons: the use of phenotypic variation in stock identification. Fish Res 43:113-128

Thompson M, Chenery S, Brett L (1989) Calibration studies in laser ablation microprobe-inductively coupled plasma atomic emission spectrometry. J Anal Atomic Spect 4: $11-16$

Thresher RE (1999) Elemental composition of otoliths as a stock delineator in fishes. Fish Res 43:165-204

Thresher RE, Proctor CH, Gunn JS, Harrowfield IR (1994) An evaluation of electron-probe microanalysis of otoliths for stock delineation and identification of nursery areas in a southern temperate groundfish, Nemadactylus macropterus (Cheilodactylidae). Fish Bull US 92:817-840

Tudela S (1999) Morphological variability in a Mediterranean, genetically homogeneous population of the European anchovy, Engraulis encrasicolus. Fish Res 42:229-243

Wells BK, Thorrold SR, Jones CM (2000) Geographic variation in trace element composition of juvenile weakfish scales. Trans Am Fish Soc 129:889-900

Whitehead PJP (1985) FAO Species catalogue, Vol 7. Clupeoid fishes of the world. Part 1. Chirocentridae, Clupeidae and Pristigasteridae. FAO Fish Syn 125:7

Submitted: August 4, 2000; Accepted: January 9, 2001

Proofs received from author(s): October 11, 2001 